\title{
The development, validation and standardisation of a questionnaire for ICT professional development of mathematics teachers
}

\begin{abstract}
Authors:
Verona Leendertz ${ }^{1}$

A. Seugnet Blignaut ${ }^{1}$

Suria Ellis ${ }^{2}$

Hercules D. Nieuwoudt ${ }^{3}$

Affiliations:

${ }^{1}$ Faculty of Economic Sciences and Information Technology, North-West University, Vaal Triangle Campus,

South Africa
\end{abstract}

${ }^{2}$ Statistical Consultation Services, North-West University, Potchefstroom Campus, South Africa

${ }^{3}$ School of Natural Science and Technology for Education, North-West University, Potchefstroom Campus, South Africa

\section{Correspondence to:}

Seugnet Blignaut

Email:

seugnet.blignaut@nwu.ac.za

Postal address:

Post Box 1174, Vanderbijlpark

9100, South Africa

\section{Dates:}

Received: 10 Apr. 2015

Accepted: 09 Sept. 2015

Published: 27 Nov. 2015

Republished: 18 Dec. 2015

\section{Note:}

This article has been republished with several corrections.

How to cite this article: Leendertz V., Blignaut A.S, Ellis S., \& Nieuwoudt, H.D. (2015). The development, validation and standardisation of a questionnaire for ICT professional development of mathematics teachers. Pythagoras, 36(2), Art. \#297,

11 pages. http://dx.doi.org/

10.4102 /pythagoras.v36i2.297

Read online:
This article reports on the development of a custom-made questionnaire. The questionnaire was developed with the aim to compile guidelines for the professional development (PD) of mathematics teachers for the pedagogical use of information and communication technology (ICT) integration in teaching and learning. During the standardisation and validation of the questionnaire it was distributed to 179 schools and 300 teachers in eight educational management districts in the Western Cape, South Africa. The extracted factors had a reliability level higher than 0.8 , which indicates the items in the questionnaire are significant to address the research problem and the questionnaire is valid for ICT PD.

\section{Introduction}

Information and communication technology (ICT) is increasingly becoming embedded in teaching and learning; it is thus imperative that teachers integrate the underpinning concepts and skills of teaching with technology into sound classroom pedagogy. Cassim (2010) conducted a secondary analysis on the South African data set of the Second Information Technology in Education Study (SITES 2006) (Pelgrum \& Law, 2008) to determine the extent to which technological pedagogical and content knowledge (TPACK) (Mishra \& Koehler, 2006) contribute towards Grade 8 mathematics teaching in South African schools. Results from this secondary data analysis revealed that the pedagogical use of ICT in mathematics teaching and learning is neither comparable to other education systems (Leendertz, Blignaut, Els, Nieuwoudt \& Ellis, 2013), nor on par with the goals stipulated in the White Paper on e-Education (Department of Education [DOE], 2004). These results indicated that there is a dire need to address the continuous professional development (PD) of mathematics teachers' ICT pedagogy, with a focus on: (1) transforming ICT mathematics education at system, school and teacher levels (Cassim, 2010) and (2) providing continuous PD to improve teachers' pedagogical use of ICT in teaching and learning in schools (Department of Basic Education [DBE], 2012). There are no guidelines for continuous PD of mathematics teachers on the pedagogical use of ICT during face-to-face teaching, in a blended environment or in open distance learning (ODL). The DBE aims for system-wide integration of ICTs into teaching and learning (DOE, 2004). There are many facets that have to be addressed before South Africa can coherently compete in the global society while adhering to the quality targets envisaged in the e-education policy (DOE, 2004). The researchers searched the Internet and significant databases for a suitable research instrument to address the research problem, but could not find a relevant questionnaire to use or adapt. They decided to compile an objective custom-made questionnaire in order to contribute to the discipline a usable instrument to measure the professional developmental needs of teachers relating to their pedagogical use of ICT for mathematics education. This article describes the compilation, validation and standardisation of an instrument for PD of mathematics teachers towards ICT integration.

\section{Research design and methodology}

The question that guided this research was: What are the processes to develop, validate and standardise a custom-made instrument for PD of mathematics teachers towards ICT integration? This question is complex and relates to the two separate social realities of objectivist and subjectivist assumptions (Burrell \& Morgan, 1979). The subjective method (adjustable exploration) focuses on the ongoing attainment and internalisation of existing knowledge and skills rooted in the known activity (Engelström, 2004) and the objective method (radical exploration) broadens the horizon of the current knowledge of the phenomenon through construction of new knowledge (Table 1). Phase I is an interpretivist phase to describe and understand the world from the perspective of those who are directly involved in the social processes (Denzin \& Lincoln, 1994) of continuous teacher PD; and Phase II is a structuralist phase rooted in a materialist view of the natural and 
TABLE 1: Two phases of the multi-mode research.

\begin{tabular}{lll}
\hline Paradigm characteristics & Phase I (Interpretivist) & Phase II (Structuralist) \\
\hline Ontology & $\begin{array}{l}\text { Understand the social phenomena through the eyes of various } \\
\text { participants in the social activity (Patton, 2002) }\end{array}$ & $\begin{array}{l}\text { Rigid and actual nature of reality which exists outside the human mind } \\
\text { (Mertens, 2010) }\end{array}$ \\
$\begin{array}{ll}\text { Epistemology } \\
\text { Derive meaning from symbols and the interpretive processes when they } \\
\text { share and interact in their environment (Merriam, 2009; Patton, 2002) }\end{array}$ & $\begin{array}{l}\text { Know the world they live in, change the world, identify the structures in } \\
\text { society and analyse the structures in society (Mack, 2010; McMillan \& } \\
\text { Schumacher, 2001) }\end{array}$ \\
Human nature & $\begin{array}{l}\text { Expert authors in PD, mathematics, ICT and ODL identified by means of a } \\
\text { systematic literature review }\end{array}$ & $\begin{array}{l}\text { Mathematics teachers in eight educational management districts in the } \\
\text { Western Cape }\end{array}$ \\
Methodology & Qualitative & Quantitative \\
& Document analysis & Questionnaire dissemination \\
\hline
\end{tabular}

$\mathrm{PD}$, professional development; ODL, open distance learning; ICT, information and communication technology.

social world that advocates sociology of radical change from an objectivist standpoint. This tactic therefore demands a multimode methodological approach which (1) enables the integration of different theoretical stances in order to answer the research question, (2) provides access to exploratory and confirmatory methods and (3) fosters the processes and outcomes of a multimode analysis (Cohen, Manion \& Morrison, 2011).

The research therefore comprised a fully multimode equal status design of the qualitative and quantitative phases (Leech \& Onwuegbuzie, 2007), which resulted in description of the data, constructive explanation of the data and hypotheses of the outcomes (Bryman, 2006). By combining the two approaches, the researchers could merge findings in order to develop new theory presented as guidelines for ICT PD of mathematics teachers (Sechrest \& Sidana, 1995).

Table 1 indicates the paradigm characteristics (ontology, epistemology, human nature and methodology) of the two phases. Phase I entails the inductive analysis of the documents selected through systematic literature review the systematic review and recording of a body of previously documented knowledge on the phenomenon of the PD of mathematics teachers for the pedagogical use of ICT in ODL. Phase II includes the distribution of a custommade questionnaire to compile guidelines for the PD of mathematics teachers towards the pedagogical use of ICT in ODL.

Survey research comprises the use of survey interviews or questionnaires. A prerequisite for the design of a good survey is deciding what is to be measured (Fowler, 2009). Generic features of questionnaires include: (1) collecting numerical data on a single data collection strategy over a large geographical area, (2) pursuing a large target population, (3) supplying explanatory and inferential information, (4) calculating frequencies, (5) standardising information (all participants complete the same questionnaire), (6) making generalisations and (7) detecting patterns according to the responses of the target population. Surveys can be either exploratory or confirmatory. While confirmatory relates to the use of an existing model, or the testing of a causal relationship or a hypothesis, exploratory relates to statements, models or patterns in the data which are consequently investigated through correlations, factor analysis, regression analysis or stepwise regression analysis (Cohen et al., 2011).
Surveys generally collect trustworthy data relating to a large number of variables (McMillan \& Schumacher, 2001) and are widely used in the social sciences to collect data on target populations relating to specific phenomena at a particular point in time (Fowler, 2009; Neuman, 2011). Surveys are often used to determine the levels of knowledge, plan intervention programmes, evaluate curricula and create intervention strategies. Surveys are designed with the aim of producing statistics about the target population (Fowler, 2009) and to generate precise, dependable and valid data, much thought and meticulous planning are required to select appropriate questions to address the research question (Neuman, 2011). For survey design and development, specific preliminary factors should be considered: (1) the motivation for the enquiry, (2) the target population of the research, (3) the availability of funding for the data collection and (4) the data collection strategy (Cohen et al., 2011).

The researchers, to no avail, searched for an existing questionnaire which could be used or modified to measure the envisaged variables of this study. Choosing a suitable questionnaire is a complex process; even more aspects come into play when designing and developing a survey (Creswell, 2012). The researchers therefore embarked on constructing a custom-made questionnaire to determine the attitudes, opinions, behaviours, characteristics and PD requirements in terms of the pedagogical use of ICT in ODL.

\section{Fourteen stages of questionnaire development}

The researchers followed the 14 stages of Cohen et al. (2011) for questionnaire design and development. Table 2 provides a succinct summary of the 14 stages.

\section{Stage 1: Aim of the questionnaire}

A questionnaire aims to gather data from a large number of respondents on the same phenomena with the intention of describing the nature of the current circumstances or to determine whether relationship exists between specific events (Cohen et al., 2011). The aim of this questionnaire was to (1) measure the professional developmental needs of teachers relating to their pedagogical use of ICT for mathematics education, (2) obtain a holistic view of the demographical outline of mathematics teachers in the Western Cape Education Department (WCED), (3) enquire about the current PD status of the teachers regarding ICT 
TABLE 2: Stages of questionnaire development.

\begin{tabular}{ll}
\hline Stages & Focus of each stage \\
\hline Stage 1 & Define the aim \\
Stage 2 & Determine which type of survey to use \\
Stage 3 & Formulate research question \\
Stage 4 & Identify the aspects on which to focus \\
Stage 5 & Clarify what information is needed to address the research question \\
Stage 6 & Determine the target population \\
Stage 7 & Compile questions and the metrics \\
Stage 8 & Make the instrument \\
Stage 9 & Determine data collection strategies \\
Stage 10 & Pilot the instrument \\
Stage 11 & Prepare for the data collection \\
Stage 12 & Collect the data \\
Stage 13 & Analyse the data \\
Stage 14 & Report the findings \\
\hline Source: Adapted from Cohen,
\end{tabular}

Source: Adapted from Cohen, L., Manion, L., \& Morrison, K. (2011). Research methods in education. (7th edn.). New York, NY: Routledge

integration and (4) use the results to develop guidelines for the professional development of mathematics teachers towards the pedagogical use of ICT in ODL.

\section{Stage 2: Select the questionnaire}

Mainly two types of questionnaires exist: cross-sectional (obtain data on present trends, attitudes and beliefs of the participants; Creswell, 2012) and longitudinal (collect data on a particular group over an extended period). This study compiled a cross-sectional questionnaire to gain the opinions of mathematics teachers about the provision of ICT resources, ICT trends, ICT teaching and learning conditions at schools and their PD needs towards ICT integration in teaching and learning. The data collection (Phase II of the study) took place as a single data collection and a cross-sectional survey was the most viable method to collect the exploratory and explanatory data (Neuman, 2011). This type of survey is relatively quick to conduct, moderately economical to administer and holds a strong probability of participation. The research collected data from a specific group of participants, subjected the data to inferential statistics and provided data for retrospective and prospective enquiry (Cohen et al., 2011) on: (1) the governance of ICT, (2) the ICT resource provision status of schools of different quintiles in the WCED, (3) the extent to which the school environment is conducive to ICT integration, (4) the current practices in ICT within mathematics classrooms, (5) the PD activities previously initiated and conducted within the WCED and (6) the PD needs and preferable modes for future PD towards ICT integration.

\section{Stage 3: Link with the research question}

The design of a questionnaire involves the translation of the research question and objectives into information embedded in the questions. It is therefore essential that the research question should be linked to the rationale of the research. The question for this study was: What are the guidelines for the $P D$ of mathematics teachers towards the pedagogical use of ICT in $O D L$ ? The survey questions were aimed at addressing this particular research question.

\section{Stage 4: Link with key aspects}

Four key variables (governance, school environment, PD and ODL) emerged as themes from the document analysis from Phase I (adjustable exploration). Each of these variables represents a section of the questionnaire with multiple subquestions; two variables (PD and ODL) were grouped into a single section with multiple sub-questions (Neuman, 2011). Additionally, the analysis required personal information from the teachers as respondents, as well as demographical information from the participating schools, in order to compare whether there were significant differences between schools in terms of context, quintile ${ }^{1}$ and socio-economic status (Cohen et al., 2011).

\section{Stage 5: Clarify information to address key aspects}

In order to address the key aspects in the research, certain categories of questions should be posed. Neuman (2011) proposes that the survey should include a list of category questions that relate to attitudes, beliefs or opinions, behaviour, characteristics, expectations, self-classification and knowledge. The researchers grouped these questions in Parts C, D, E and F of the questionnaire according to the identified themes.

\section{Stage 6: Determine the target population}

Sampling is an integral part in the survey approach (Cohen et al., 2011). Funds available for collecting data, time available for the data collection and access to the respondents are aspects that the researchers have to take into consideration at the onset of the research before samples of participants are selected (Cohen et al., 2011). The five key factors that influence sampling are: (1) sample size, (2) representation and restrictions of the sample, (3) means of contact with the sample, (4) sample selection strategy and (5) the research methodology. As soon as these aspects have been addressed, the sample selection can be performed.

The target population is a specified large group of many subjects from which a researcher draws a sample (Neuman, 2011). A sample is a set of units a researcher chooses from the large group and generalises to a particular population (Neuman, 2011). Sample selection is a critical component of research which is guided by the type of analysis being performed. Sampling in quantitative research is when a researcher selects units and regards them as representative of the total population. The features of the sample should emphasise key elements in a complex social world in order to give clarity about and insight and understanding into the concerns in the social world (Neuman, 2011). It is therefore important that the researchers make sampling decisions during the initial planning of the research project (Cohen et al., 2011; Neuman, 2011).

\footnotetext{
1.A quintile is a cut-off point to receive a subsidy from the government for the provision of resources.
} 
The systematic literature analysis revealed various ICT projects in South Africa since the launch of the e-education policy (DOE, 2004). Western Cape teachers received extensive ICT training through the Khanya Project (WCED, 2011) and therefore the Western Cape was identified as the most viable target population. The mathematics teachers of the WCED were therefore the target population for this study.

The researchers considered five key factors when selecting the sample: (1) the sample size, (2) the symbolisation and limitation of the sample, (3) access to the sample, (4) the use of a sample strategy and (5) the conduct of research. There is no clear-cut method to select an appropriate sample (Neuman, 2011). It is an intricate process which depends on: (1) the aim of the study, (2) the characteristics of the population under study, (3) the level of accuracy needed from the data, (4) the response rate estimated from the data collection, (5) the number of variables included in the study and (6) the research methodology used for the study (Cohen et al., 2011). For quantitative research a large sample is beneficial as larger samples contribute towards increased reliability and the use of sophisticated statistical procedures demands a large number of observations. The researchers applied the eight stages of planning a sample strategy according to Cohen et al. (2011). Table 3 provides a summary of the planning stages of the sample selection procedure of this research.

The WCED is divided into eight education districts: four rural districts, which correspond to one or more municipalities, and four urban or metro districts located within the City of Cape Town. Each educational management district has a district director, a circuit team with a circuit team manager who coordinates the tasks of the curriculum advisors, Special Needs Education professionals, Institutional Management and Governance planning and a School Governance and Management team (WCED, 2013).

\section{Stage 7: Compile the questions and the metrics}

Babbie (2010) and McMillan and Schumacher (2001) propose that a researcher formulate questions and constructs to: (1) operationalise the variables of the research, (2) collect data for analysis and interpretation, (3) ensure maximum response and (4) extract data for analysis to address the research problem. This formulation procedure should take into account:

TABLE 3: Stages in sample selection.

\begin{tabular}{|c|c|}
\hline Stage & Activities \\
\hline 1 & Identify WCED schools as target population \\
\hline 2 & $\begin{array}{l}\text { Identify senior phase (Grades } 7-9 \text { ) mathematics teachers as subjects from } \\
\text { the population }\end{array}$ \\
\hline 3 & Select sample with the assistance of co-promoter, a senior statistician \\
\hline 4 & Access WCED EMIS database to locate sample schools \\
\hline 5 & Identify participating schools through systematic random cluster sampling \\
\hline 6 & Build redundancy through oversampling \\
\hline 7 & List contact information of participating WCED schools \\
\hline 8 & Adjust sample according to circumstantial conditions at grassroots \\
\hline
\end{tabular}

- General question format. The arrangement of the questions in the questionnaire is of equal importance to the nature and wording of the questions asked. Jumbled and shortly phrased questions confuse respondents and can lead to respondents not replying to questionnaire items (Babbie, 2010). The researchers planned the layout of the questions in the questionnaire to optimally use space and yet simultaneously contribute towards readability. The researchers consulted a language expert to assist with the wording of the questions.

- Usable format for respondents. The researchers provided tick boxes to capture responses easily. For Parts C-F of the questionnaire, the researchers used a five-point Likert scale ( 1 = strongly agree; 2 = agree; 3 = strongly disagree; 4 = disagree; 5 = do not know).

- Ordering of items in the questionnaire. The researchers placed the demographic data at the beginning of the questionnaire (Parts A and B) to provide an easy start and put the respondents at ease. The more complex questions on attitudes, attributes, opportunities, self-classification and knowledge followed in Parts C- G.

- Questionnaire instructions. A cover letter introduced the background and the rationale for the research, followed by basic instructions on how to complete the questionnaire.

- Pretesting of the questionnaire. To ensure that the questions were clear and unambiguous, the researchers approached mathematics teachers to assess the readability and layout of the questionnaire.

- Data processing. A data processing pane on the questionnaire was created: (1) to assist the researchers during the capturing and checking of the data and (2) for respondents to see which data would be used for the analysis (Babbie, 2010; McMillan \& Schumacher, 2001). Table 4 provides a synopsis of the seven guidelines used during the compilation of the questionnaire.

\section{Stage 8: Create the questionnaire}

The researchers compiled the questionnaire according to the seven identified parts.

TABLE 4: Seven guidelines to formulate questions.

\begin{tabular}{ll}
\hline Guideline & Rationale \\
\hline Formulate clear questions & $\begin{array}{l}\text { Respondents interpret the text in the same } \\
\text { way; no unclear words }\end{array}$ \\
$\begin{array}{l}\text { Avoid double-barrelled questions } \\
\text { Match the level and tone of } \\
\text { questionnaire to the characteristics } \\
\text { of the target respondents }\end{array}$ & $\begin{array}{l}\text { Respondents should feel compelled to supply } \\
\text { trustworthy responses }\end{array}$ \\
$\begin{array}{l}\text { Ensure the relevance of the } \\
\text { questions }\end{array}$ & $\begin{array}{l}\text { Respondents should be able to respond } \\
\text { to the questions based on their lived } \\
\text { experiences }\end{array}$ \\
Pose short, simple questions & $\begin{array}{l}\text { Shorter questions ensure respondents are } \\
\text { able to read and respond quickly }\end{array}$ \\
Avoid negative items & $\begin{array}{l}\text { Respondents cannot misinterpret the } \\
\text { question and be unsure how to approach the } \\
\text { question }\end{array}$ \\
Avoid biased items or terms & $\begin{array}{l}\text { Avoid formulating questions in order to } \\
\text { influence the intended outcomes }\end{array}$ \\
\hline
\end{tabular}

Source: Adapted from Babbie, E.R. (2010). The practice of social research. Belmont, CA: Wadsworth; McMillan, J.H., \& Schumacher, S. (2001). Research in education: A conceptual introduction. (5th edn.). New York, NY: Addison Wesley Longman. 


\section{Parts A and B: Personal and demographical information}

Part A requested personal information of the respondents: (1) gender, (2) age, (3) home language, (4) language of instruction, (5) years of teaching experience in the various grades, (6) highest qualification or highest professional qualification and (7) subject specialisation. Part B comprised demographical information relating to the: (1) school district, (2) nearest town or city, (3) geographical location (rural or urban area), (4) quintile of the school, (5) number of mathematics classes per grade, (6) number of mathematics classes teachers teach, (7) availability of computers for teaching, learning and administration and (8) access to the Internet for administration, teaching and learning. For some questions, the respondents had to select the appropriate option or fill in the applicable response.

\section{Parts C-F: Governance, school environment, information and communication technology, professional development and open and distance learning}

Parts C-F comprised complex questions on attitudes, attributes, opportunities, self-classification and knowledge relating to the research. Part G relates to PD models. Parts C-F posed questionnaire items relating to the four themes (governance; school environment; ODL; PD). The selected quotations from the qualitative analysis illustrate the underlying constructs. A closed form method of a five-point Likert scale ( $1=$ strongly agree, 2 = agree, 3 = strongly disagree, $4=$ agree, $5=$ do not know) pinpoints respondents' inputs. Table 5 provides an example of the compilation of the questions and illustrates the relationship between the literature constructs as derived from the literature review and the individual questions.

Part $C$ of the questionnaire addressed the governance of ICT implementation at provincial (WCED), district and school level. The majority of the items in this section relate to the objectives of the three-phase ICT integration plan as stipulated in the White Paper on e-Education (DOE, 2004).

Aspects relating to the school environment were grouped as one part of the questionnaire with various sub-questions
(Part D). The questions relate to aspects regarding the extent to which mathematics teachers: (1) create a classroom environment where they utilise the Internet and ICT applications, (2) download resources, (3) develop lessons with the help of ICT, (4) stimulate their learners to be creative, (5) use the vast array of resources to improve their academic performance, (6) achieve the assessment standards and (7) have a positive attitude towards the use of ICT for teaching and learning of mathematics.

In Part F, the researchers aimed to: (1) confront issues about PD of mathematics teachers, (2) gain insight into the opinions of mathematics teachers on future PD opportunities, (3) learn about the context in which PD activities should occur and (4) assess the modes in which PD should take place.

\section{Part G: Professional development models}

The final part of the questionnaire (Part G) included four PD models conceptualised using the multiple PD models and frameworks identified in the literature review. The researchers adapted a variety of PD models, tested in other education systems across the world by the expert researchers in this particular field, to suit the background and context of South African schools. The four models included the best practices for PD that could work in the South African context.

\section{Stage 9: Determine the data collection strategy}

The data collection of a survey can be conducted via a postal interviews, personal interview, telephone, and Internet-based surveys. Each of these strategies has its own strengths and weaknesses (Cohen et al., 2011). The researchers administered the questionnaire by personally delivering it to respondents and again collecting it from their individual sampled schools.

\section{Stage 10: Piloting the questionnaire}

The validation of the questionnaire before distribution to the participants is critical. Two components have to be piloted: (1) the instructions to the respondents and (2) the questionnaire

TABLE 5: Description of compilation of questions for Parts C-F

\begin{tabular}{|c|c|c|}
\hline \multicolumn{2}{|c|}{ Question } & \multirow{2}{*}{$\begin{array}{l}\text { Themes from inductive systematic literature analysis } \\
\text { Promote effective practices in the use of ICTs in teaching and learning (DOE, 2004) }\end{array}$} \\
\hline $\mathrm{C} 1$ & $\begin{array}{l}\text { The WCED motivates for the use of ICT in } \\
\text { mathematics teaching }\end{array}$ & \\
\hline $\mathrm{C2}$ & $\begin{array}{l}\text { The WCED allocates funds for ICT mathematics } \\
\text { training }\end{array}$ & The DBE provides access to technology, including teacher development (DOE, 2004) \\
\hline C3 & The WCED provides funding for ICT resources & Building an integrated e-education system requires better investment in the education sector (DOE, 2004) \\
\hline D1 & $\begin{array}{l}\text { I use social software for personal use, e.g. email, } \\
\text { Facebook, Twitter, Mxit, WhatsApp, BBM }\end{array}$ & Many researchers recognise the value of social software in ICT PD (Ala-Mutka, Punie \& Redecker, 2010) \\
\hline D2 & I use the Internet to find mathematics resources & $\begin{array}{l}\text { The Internet can be a tool to search for new developments in mathematics teaching and learning (Da Ponte, Oliveira } \\
\& \text { Varandas, 2002) }\end{array}$ \\
\hline D3 & $\begin{array}{l}\text { I use ICT in mathematics teaching to achieve the } \\
\text { learning outcomes }\end{array}$ & $\begin{array}{l}\text { During training teachers use ICT in problem-solving, producing mathematics lessons and creating new problems } \\
\text { (Swan et al., 2002) }\end{array}$ \\
\hline E1 & $\begin{array}{l}\text { My school negotiates with service providers for } \\
\text { reliable Internet access }\end{array}$ & $\begin{array}{l}\text { Stakeholders negotiate easier access to reduce costs for Internet-enabled devices (Department of Higher Education } \\
\text { and Training, 2012) }\end{array}$ \\
\hline E2 & My school has an ICT policy & Every South African learner will have the capability to function within an ICT environment by 2013 (DOE, 2004) \\
\hline E3 & My school has teachers who use ICT innovatively & Schools should have skilled and capable teachers who use ICT to enhance teaching and learning (DOE, 2004) \\
\hline F1 & I develop my mathematics competencies myself & Teacher's own attitude regarding their development (Da Ponte, 2010) \\
\hline F2 & $\begin{array}{l}\text { I know about the current trends in mathematics } \\
\text { education }\end{array}$ & $\begin{array}{l}\text { The structure of the teachers' activity has undergone important changes involving new curriculum goals and } \\
\text { professional responsibilities (Da Ponte, 2010) }\end{array}$ \\
\hline F3 & I am innovative with ICT in my mathematics teaching & Teachers to explore new ways of using this technology (Da Ponte, 2010) \\
\hline
\end{tabular}


itself (McMillan \& Schumacher, 2001). After compilation of the initial questionnaire, it was formally peer reviewed by five mathematics lecturers at the Unit for Open Distance Learning at the authors' university. Subsequently the researchers piloted the questionnaire with: (1) two mathematics teachers from a quintile 1 school, (2) two mathematics teachers from a quintile 3 school and (3) one mathematics teacher from a quintile 5 school. This contributed towards the validity and reliability of the questions and ensured the comprehensiveness of the questionnaire (Cohen et al., 2011; Strydom, 2005).

\section{Stage 11: Prepare for data collection}

Before data collection the researchers obtained ethical clearance from the university's ethics committee and permission from the WCED to distribute the questionnaire in the eight education districts. Ethical clearance ensures that the respondents are protected from harm and that the researcher ensures the respondents of confidentiality, anonymity and the nontraceability of their participation in the research. The researchers planned the data collection in accordance with the schedule of the district offices and contacted the relevant parties (subject advisors, schools) via email and followed up by telephone.

\section{Stage 12: Collect data}

The first author confirmed the appointments for the data collection sessions and visits to schools telephonically and travelled in 37 days a total of $9287 \mathrm{~km}$ in order to collect the data. This was a considerable task in terms of man-hours and cost. The researchers collected data from farm, semi-urban, urban, former Model C and independent schools across the districts.

\section{Stage 13: Analyse the data}

Various statistical procedures (descriptive statistics, factor analysis and structural equation modelling) were followed to analyse the collected data.

\section{Parts A and B: Descriptive statistics}

The biographical information was presented with frequencies and percentages. Table 6 outlines the summary of the biographical information. Both men (45\%) and women (55\%) were well represented, from the eight education districts in the Western Cape, with a good distribution in age, teaching experience, language, qualification, quintile and type of school.

TABLE 6: Descriptive statistics for Parts A and B.

\begin{tabular}{|c|c|c|c|c|c|}
\hline & & & & Frequencies & Percentages \\
\hline \multirow[t]{2}{*}{ A1 } & Gender & & Male & 135 & 45 \\
\hline & & & Female & 165 & 55 \\
\hline \multirow[t]{5}{*}{ A2 } & Age & & $20-29$ & 66 & 22 \\
\hline & & & 30-39 & 71 & 24 \\
\hline & & & $40-49$ & 95 & 35 \\
\hline & & & $50-59$ & 57 & 29 \\
\hline & & & $60+$ & 11 & 4 \\
\hline \multirow[t]{5}{*}{ A3 } & Total number of years teaching & & $0-9$ years & 113 & 38 \\
\hline & & & $10-19$ years & 78 & 26 \\
\hline & & & $20-29$ years & 77 & 26 \\
\hline & & & $30-39$ years & 28 & 9 \\
\hline & & & $40+$ & 4 & 1 \\
\hline \multirow[t]{12}{*}{ A4 } & Total number of years teaching mathematics & Grade 7 & 0 years & 230 & 77 \\
\hline & & & $1-9$ years & 43 & 14 \\
\hline & & & $10-19$ years & 14 & 5 \\
\hline & & & 20-40 years & 13 & 4 \\
\hline & & Grade 8 & 0 years & 73 & 24 \\
\hline & & & $1-9$ years & 137 & 46 \\
\hline & & & $10-19$ years & 41 & 14 \\
\hline & & & $20-40$ years & 49 & 16 \\
\hline & & Grade 9 & 0 years & 50 & 17 \\
\hline & & & $1-9$ years & 151 & 51 \\
\hline & & & $10-19$ years & 42 & 14 \\
\hline & & & 20-40 years & 55 & 18 \\
\hline \multirow[t]{3}{*}{ A5 } & Home language & & English & 58 & 19 \\
\hline & & & Afrikaans & 188 & 63 \\
\hline & & & isiXhosa & 54 & 18 \\
\hline \multirow[t]{2}{*}{ A6 } & Language of instruction & & English & 133 & 44 \\
\hline & & & Afrikaans & 167 & 56 \\
\hline \multirow[t]{6}{*}{ A7 } & Qualifications & & DE III & 21 & 7 \\
\hline & & & $\mathrm{HDE} / \mathrm{ACE}$ & 89 & 30 \\
\hline & & & BEd & 45 & 15 \\
\hline & & & $\mathrm{BA} / \mathrm{BSC}$ & 70 & 23 \\
\hline & & & Post graduate & 42 & 14 \\
\hline & & & Other & 33 & 11 \\
\hline \multirow[t]{2}{*}{ A8 } & Subject specialisation & & Mathematics & 252 & 84 \\
\hline & & & Other & 48 & 16 \\
\hline
\end{tabular}


TABLE 6: (Continued) Descriptive statistics for Parts A and B.

\begin{tabular}{|c|c|c|c|c|c|}
\hline & & & & Frequencies & Percentages \\
\hline \multirow[t]{7}{*}{ B1 } & \multirow[t]{7}{*}{ School district } & & Metro Central & 40 & 13 \\
\hline & & & Metro East & 46 & 15 \\
\hline & & & Metro North & 17 & 6 \\
\hline & & & Metro South & 28 & 9 \\
\hline & & & Cape Winelands & 68 & 23 \\
\hline & & & Eden Central Karoo & 54 & 18 \\
\hline & & & Overberg & 5 & 2 \\
\hline \multirow[t]{6}{*}{ B4 } & \multirow[t]{6}{*}{ School quintile } & & 1 & 52 & 17 \\
\hline & & & 2 & 21 & 7 \\
\hline & & & 3 & 56 & 19 \\
\hline & & & 4 & 61 & 20 \\
\hline & & & 5 & 95 & 32 \\
\hline & & & Independent & 15 & 5 \\
\hline \multirow[t]{4}{*}{ B5 } & \multirow[t]{4}{*}{ Type of school } & & Farm & 15 & 5 \\
\hline & & & Urban & 86 & 29 \\
\hline & & & Former Model C & 76 & 25 \\
\hline & & & Independent & 16 & 5 \\
\hline \multirow[t]{3}{*}{ B6 } & \multirow[t]{3}{*}{ Number of learners at school } & & $0-500$ & 53 & 18 \\
\hline & & & $500-1000$ & 117 & 39 \\
\hline & & & $1000+$ & 130 & 43 \\
\hline \multirow[t]{7}{*}{ B10 } & \multirow[t]{7}{*}{ Number of computer laboratories } & & 0 & 15 & 5 \\
\hline & & & 1 & 143 & 48 \\
\hline & & & 2 & 88 & 29 \\
\hline & & & 3 & 45 & 15 \\
\hline & & & 4 & 8 & 3 \\
\hline & & & 5 & 0 & 0 \\
\hline & & & 6 & 1 & 0 \\
\hline \multirow[t]{3}{*}{ B11 } & \multirow[t]{3}{*}{ Computers at my school available for } & & Administration & 286 & 95 \\
\hline & & & General teaching & 242 & 81 \\
\hline & & & Mathematics Grade 9 & 159 & 53 \\
\hline \multirow[t]{10}{*}{ B12 } & \multirow{2}{*}{$\begin{array}{l}\text { Computers with Internet available for } \\
\text { administration }\end{array}$} & & Yes & 286 & 95 \\
\hline & & & No & 14 & 5 \\
\hline & \multirow{2}{*}{$\begin{array}{l}\text { Computers with Internet available for } \\
\text { general teaching }\end{array}$} & & Yes & 214 & 71 \\
\hline & & & No & 86 & 29 \\
\hline & \multirow{6}{*}{$\begin{array}{l}\text { Computers with Internet available for } \\
\text { mathematics teaching in }\end{array}$} & Grade 7 & Yes & 38 & 13 \\
\hline & & & No & 262 & 87 \\
\hline & & Grade 8 & Yes & 126 & 42 \\
\hline & & & No & 174 & 58 \\
\hline & & Grade 9 & Yes & 144 & 48 \\
\hline & & & No & 156 & 52 \\
\hline \multirow[t]{4}{*}{ B13 } & I rate my computer literacy level as & & Poor & 24 & 8 \\
\hline & & & Fair & 73 & 24 \\
\hline & & & Good & 153 & 51 \\
\hline & & & Excellent & 51 & 17 \\
\hline B15 & Personal computers available & School & Yes & 195 & 65 \\
\hline & & & No & 105 & 35 \\
\hline & & Home & Yes & 258 & 86 \\
\hline & & & No & 42 & 14 \\
\hline B16 & Internet access & Home & Yes & 195 & 65 \\
\hline & & & No & 105 & 35 \\
\hline B17 & Interactive whiteboards at school & & Yes & 163 & 54 \\
\hline & & & No & 138 & 46 \\
\hline B18 & Online course & & Yes & 32 & 11 \\
\hline & & & No & 268 & 89 \\
\hline
\end{tabular}

Only $7 \%$ of the mathematics teachers held a NQF level five qualification; $14 \%$ of the mathematics teachers had postgraduate degrees (Table 6). The majority (84\%) specialised in mathematics teaching and $16 \%$ had no formal mathematics qualification. Only $5 \%$ of the participating schools in the Western Cape did not have computer laboratories. Few mathematics teachers $(8 \%)$ rated their computer literacy as poor; in general they had adequate access to computers, 
interactive whiteboards and the Internet either at home or school. However, only $11 \%$ had experience of participating in some sort of online course.

\section{Factor analysis}

The researchers applied construct validity through factor analysis to group the items of the questionnaire meaningfully. Using construct validity validates the extent to which the questionnaire used in this research for data collection corresponds with the theoretical context (Cohen et al., 2011; Neuman, 2011). After factor analysis had been conducted on Parts C-F, the researchers performed a reliability test using Cronbach's alpha, applying an acceptable reliability level of 0.7 , to test whether the extracted frequencies were significant and if the items within the questionnaire were valid. This study used representative reliability: (1) to make ensure that the data and findings were suitable, predictable, reliable and replicable and (2) to minimise the external sources of variation in the data (excluding acute answers from the data analysis) (Cohen et al., 2011; Neuman, 2011). For the alpha coefficient the following categories applied to this factor analysis:

- > 0.90: very highly reliable

- 0.80-0.90: highly reliable

- 0.70-0.79: reliable

- 0.60-0.69: marginally reliable

- $\leq 0.60$ : low reliability

The questionnaire included subscales; therefore the reliability of each set of factors was calculated individually. The factors were extracted according to Kaiser's criteria and 10 of the 11 extracted factors had a reliability level higher than 0.8 , which indicates the items in the questionnaire are significant to address the research problem.

Table 7 illustrates the pattern matrix of the correlation coefficient between the factors in Parts C-F. Variables with factor loadings of 0.3 or lower were extracted from the tables and variables with more than one factor loading were grouped according to best interpretability. Each factor was scrutinised, evaluated and named according to a theme best suited to the factor. The Barlett's test of sphericity showed a significance (p) of less than 0.0001 for the factor analysis from Parts C-F.

\section{Factor analysis: Part C}

Four factors were extracted with the factor analysis. The Kaiser Meyer Olkin (KMO) measure of 0.912 indicated adequate data for factor analysis with a total variance of $59 \%$. Communalities varied from $40 \%$ for Factor 1 and 50\% for Factor 2 to $55 \%$ for Factor 3 and 59\% for Factor 4 . The factors showed a high reliability of 0.95 for Factor 1, 0.85 for Factor 2, 0.81 for Factor 3 and 0.88 for Factor 4 . The four factors were named: responsibility of DBE) (Factor 1), responsibility of management (Factor 2), responsibility of teaching and learning (Factor 3) and policy initiatives (Factor 4).

The mean of 3.26 for responsibility of DBE indicates that mathematics teachers in general think that it is the responsibility of DBE is to administer ICT integration at

TABLE 7: Pattern matrix of factor analysis for Parts C-F.

\begin{tabular}{|c|c|c|c|c|c|c|c|c|c|c|c|}
\hline \multirow{2}{*}{$\begin{array}{l}\text { Number of } \\
\text { items }\end{array}$} & \multicolumn{4}{|c|}{ Factors in Part C } & \multicolumn{2}{|c|}{ Factors in Part D } & \multicolumn{2}{|c|}{ Factors in Part E } & \multicolumn{3}{|c|}{ Factors in Part F } \\
\hline & 1 & 2 & 3 & 4 & 1 & 2 & 1 & 2 & 1 & 2 & 3 \\
\hline 1 & 0.569 & - & - & - & 0.692 & - & 0.661 & - & 0.655 & - & - \\
\hline 2 & 0.652 & - & - & - & 0.480 & - & 0.839 & - & 0.684 & - & - \\
\hline 3 & 0.898 & - & - & - & - & 0.619 & 0.514 & - & 0.803 & - & - \\
\hline 4 & 1.004 & - & - & - & - & 0.713 & 0.662 & - & 0.773 & - & - \\
\hline 5 & 0.906 & - & - & - & - & 0.865 & - & 0.742 & 0.716 & - & - \\
\hline 6 & 0.763 & - & - & - & - & 0.814 & - & 0.828 & 0.831 & - & - \\
\hline 7 & - & 0.309 & - & - & - & 0.856 & - & 0.732 & 0.753 & - & - \\
\hline 8 & - & 0.486 & - & - & - & 0.614 & - & 0.461 & 0.723 & - & - \\
\hline 9 & - & 0.520 & - & - & - & 0.345 & - & 0.934 & - & 0.447 & - \\
\hline 10 & - & 0.628 & - & - & - & 0.903 & - & 0.704 & - & 0.755 & - \\
\hline 11 & - & 0.819 & - & - & - & 0.901 & - & - & - & 0.769 & - \\
\hline 12 & - & 0.826 & - & - & - & 0.909 & - & - & - & 0.918 & - \\
\hline 13 & - & 0.533 & - & - & - & - & - & - & - & 0.755 & - \\
\hline 14 & - & - & 0.485 & - & - & - & - & - & - & 0.380 & - \\
\hline 15 & - & - & 0.617 & - & - & - & - & - & - & 0.529 & - \\
\hline 16 & - & - & 0.610 & - & - & - & - & - & - & - & -0.427 \\
\hline 17 & - & - & 0.833 & - & - & - & - & - & - & - & -0.330 \\
\hline 18 & - & - & 0.653 & - & - & - & - & - & - & - & -0.892 \\
\hline 19 & - & - & 0.404 & - & - & - & - & - & - & - & -0.451 \\
\hline 20 & - & - & - & 0.440 & - & - & - & - & - & - & - \\
\hline 21 & - & - & - & 0.691 & - & - & - & - & - & - & - \\
\hline 22 & - & - & - & 0.653 & - & - & - & - & - & - & - \\
\hline 23 & - & - & - & 0.657 & - & - & - & - & - & - & - \\
\hline Cronbach's alpha & 0.95 & 0.85 & 0.81 & 0.88 & 0.58 & 0.94 & 0.80 & 0.88 & 0.92 & 0.87 & 0.87 \\
\hline Mean & 3.26 & 2.92 & 3.24 & 3.24 & 3.19 & 2.71 & 3.26 & 2.62 & 3.19 & 3.23 & 3.26 \\
\hline Standard deviation & 1.204 & 0.768 & 0.977 & 0.926 & 0.601 & 0.709 & 0.917 & 0.774 & 0.548 & 0.450 & 0.503 \\
\hline
\end{tabular}


schools in the WCED, ensure that intervention strategies are in place for Phase III of the e-education policy and provide PD towards ICT integration. Mathematics teachers did not all regard ICT integration to be the responsibility of management (mean 2.92). Some mathematics teachers were of the opinion that the school management team should have an ICT strategic plan for: (1) providing access to ICT tools for teaching and learning, (2) creating a timetable for admission to ICT facilities and (3) affording time to prepare ICT integration lessons. The mean of 3.24 for policy initiatives indicates that mathematics teachers in the WCED agree that previous and current ICT initiatives do not address their needs for ICT integration in mathematics teaching and learning (Table 7).

\section{Factor analysis: Part D}

Two factors were extracted with a KMO measure of 0.906 indicating adequate data for factor analysis with a total variance of $59 \%$. Communalities varied from 53\% for Factor 1 to $61 \%$ for Factor 2. The factors showed a marginal reliability of 0.60 for Factor 1 and 0.71 for Factor 2. Factor 1 relates to technology knowledge (TK), and Factor 2 corresponds with technological pedagogical and content knowledge (TPACK).

A mean of 3.19 for TK indicates that quite a few teachers regard TK as more important than TPACK. They believe that if they understand ICT, they can (1) use it in their daily lives, (2) employ it in their work environment and (3) identify when ICT can complement other methods to achieve the learning outcomes for mathematics. The mean of 2.71 for TPACK indicates that some mathematics teachers regard ICT pedagogical skills to impart knowledge and skills as less important (Table 7).

\section{Factor analysis: Part E}

Two factors were extracted with the KMO measure of 0.893 indicating adequate data for factor analysis with a total variance of 55\%. Communalities varied from $46 \%$ for Factor 1 to $55 \%$ for Factor 2. The factors showed a high reliability of 0.92 for Factor 1 and a reliability of 0.78 for Factor 2. Factor 1 relates to contributors to social professional identity (SPI) and Factor 2 corresponds with ICT and social professional development $(S P D)$.

A mean of 3.26 for contributors to SPI indicates that holistic growth through self-awareness and constructive socialisation is critical to many mathematics teachers. Mathematics teachers should have Internet access so that they can create a network with other mathematics teachers to discuss their uncertainties and share their best practices. A mean of 2.62 for ICT and SPD indicates that mathematics teachers regard their holistic growth through social interaction as more important than the extent to which they use ICT to add to their SPD (see Table 7).

\section{Factor analysis: Part F}

Three factors were extracted with the KMO measure of 0.927 indicating adequate data for factor analysis with a total variance of $55 \%$. Communalities varied from $50 \%$ for Factor 1 to $57 \%$ for Factor 2 and 61\% for Factor 3. The factors showed a high reliability: of 0.92 for Factor 1, 0.87 for Factor 2 and 0.87 for Factor 3. Factor 1 relates to teachers' expectations for PD, Factor 2 corresponds with building a SPI and Factor 3 relates to $P D$ models and frameworks.

Means of 3.19 for teachers' expectations for PD, 3.23 for building a SPI and 3.26 for PD models and frameworks indicate that mathematics teachers in the WCED regard all these as important during PD. Mathematics teachers expect the DBE, provincial departments and schools to work together to develop an ICT strategic plan, which includes a PD model that is versatile, so that they can develop at their own pace, perceptive to address subjectspecialised training and insightful to their developmental needs (Table 7).

\section{Part G: Structural equation modelling}

The aim of the structural equation model was to determine whether there were statistically significant relationships between the four themes. Table 8 indicates the statistically significant relationship between governance and school environment $(p<0.05)$ and between school environment and ODL $(p<0.05)$. The standardised regression weight for governance and school environment was 0.61 and for ODL and school environment was 0.97. Although not statistically significant, the standardised regression weight for ODL and PD was -0.90 and for school environment and PD was 1.07. The standardised regression coefficients indicated that when correlations between variables were taken into account, governance had a positive influence on school environment and ODL, and school environment had a positive influence on ODL and PD. However, ODL had a negative influence on PD (see Table 8).

Figure 1 illustrates the structural equation model from governance, school environment, ODL and PD. The comparative fit index (CFI), also known as the Bentler Comparative fit statistic, compares the fit of a target model to the fit of an independent model. The goodness-of-fit measures for the model comprised:

- Chi-square test statistic divided by its degrees of freedom (CMIN/DF) value of 3.40, which was less than 5, which indicated a good fit.

- CFI value of 0.88 , which indicated an acceptable overall fit (Mueller, 1996).

TABLE 8: Standardised regression weights and correlations between governance, school environment, open distance learning and professional development.

\begin{tabular}{lcc}
\hline Activity system & Standardised regression weight & $p$ value \\
\hline Environment $\leftarrow$ Governance & 0.61 & $* * * * *$ \\
Environment $\leftarrow$ Open distance & 0.97 & $* * * * *$ \\
learning & & \\
PD $\leftarrow \leftarrow$ Open distance learning & -0.90 & 0.594 \\
PD Environment & 1.07 & 0.533 \\
\hline$* * * *, p<0.05$. & &
\end{tabular}

PD, professional development
P 


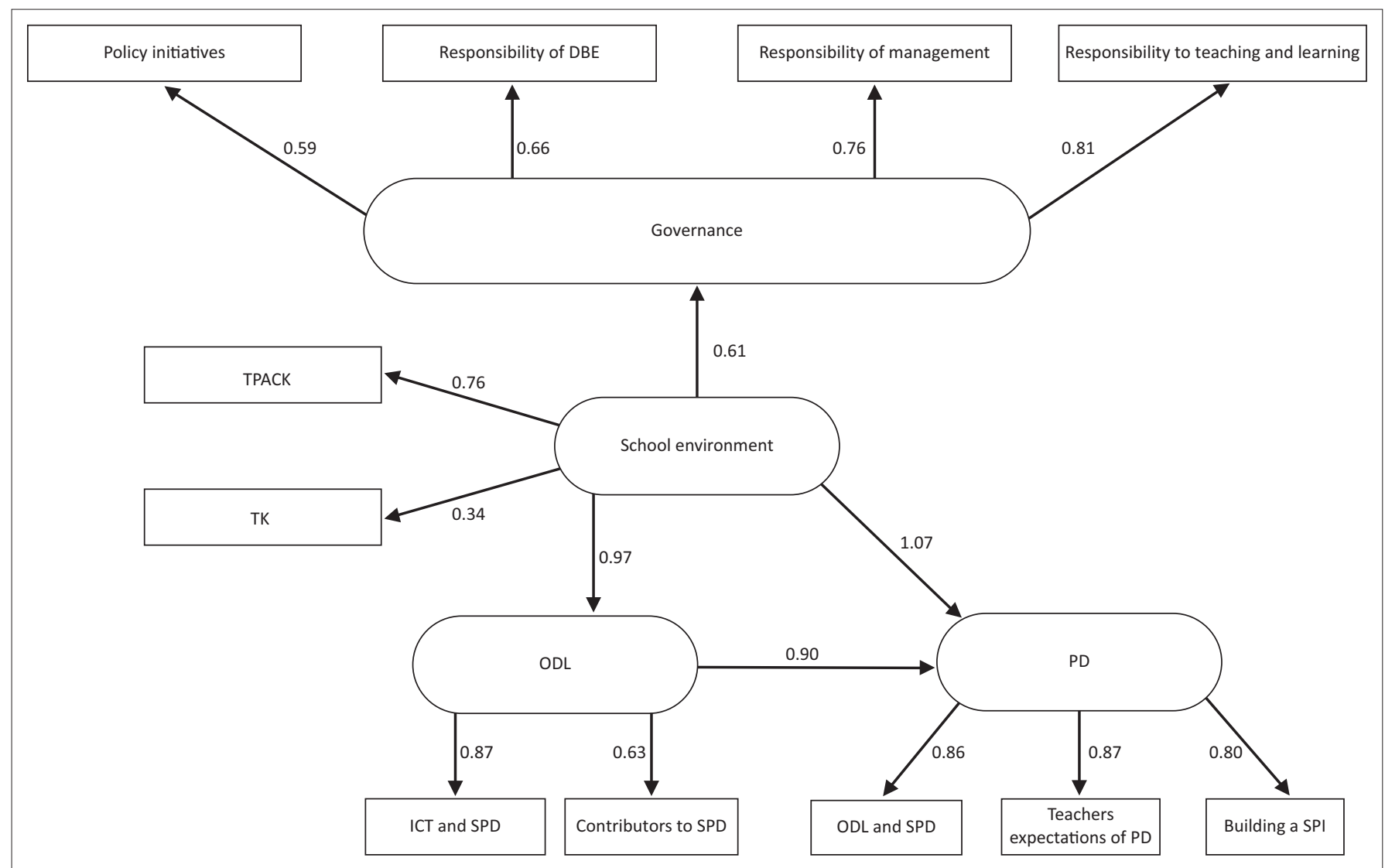

TK, technology knowledge; ODL, open distance learning; PD, professional development; ICT, information and communication technology; SPD, social professional development; SPI, social professional identity

FIGURE 1: Structural equation model from governance, school environment, open distance learning and professional development.

Root mean square error of approximation measures the differences in the observed values in the model. A value of 0.11 was not smaller than 0.1 for unacceptable fit (Blunch, 2008).

The structural equation model illustrates the validation of how the four themes were supportive towards achieving the object of the research. Even though ODL has a negative influence on PD; ODL is a new mode of service delivery in terms of PD in the current education system in South Africa. When teachers become acquainted with PD through ODL, and the benefits thereof, their perceptions and attitudes towards ODL as a method of PD may change.

\section{Stage 14: Report the findings}

The first author wrote a full report on the findings from the statistical analysis with clear guidelines for the PD of mathematics teachers for the pedagogical use of ICT in ODL. Additionally the research: (1) developed a model for identity essentials for PD for mathematics teachers in South Africa and (2) compiled strategies on how to conduct systematic literature and quantise literature data through exploratory factor analysis. The researchers are in the process of: (1) distributing the questionnaire in Finland to do a comparison between PD needs of mathematics teachers in the two contexts and (2) constructing national guidelines for PD for ICT integration.

\section{Conclusions}

With the 14 stages of questionnaire development, the research developed, validated and standardised an instrument for PD of mathematics teachers for the pedagogical use of ICT, which (1) enables each context to assess the PD requirements, (2) gives access to the developmental needs of mathematics teachers to allow for the creation of context-specific PD programmes and (3) can consequently be used by other researchers to compare the contexts of other South African provinces, as well as to explore and describe PD needs in diverse contexts.

The factor analysis extracted factors with high reliability which accentuates the value of the analysis. From the results it became clear that fundamentally ICT integration and implementation initiatives start with the DBE. Before developing future PD which aligns with the continuous teacher PD management system and Phase III of the e-education policy, the DBE should appoint a DBE panel comprising national and provincial ICT coordinators. Once all the groundwork has been done they can plan future ICT initiatives, develop PD models that suit the South African school context and supply the provincial education departments and schools with guidelines for PD. The DBE should invest in the provision of ICT equipment and human capital, reinstate the laptop initiative for teachers and supply 
schools with networked computer facilities so that they can explore online platforms for PD.

\section{Acknowledgements}

This work is based on research conducted for a PhD study. The research is in part funded by the National Research Foundation of South Africa. Any opinions, findings and conclusions or recommendations expressed in this material are those of the authors and therefore the NRF does not accept any liability in regard thereto.

\section{Competing interests}

The authors declare that they have no financial or personal relationships that may have inappropriately influenced them in writing this article.

\section{Authors' contributions}

V.L. (North-West University) was the main author of the article. A.S.B. (North-West University) assisted with the qualitative analysis and to create constructs. S.E. (North-West University) was the co-promoter and statistician and assisted with the structure, scales and quantitative analysis. H.D.N. (North-West University) assisted with the interpretation of the quantitative analysis.

\section{References}

Ala-Mutka, A., Punie, Y., \& Redecker, C. (2010). Learning 2.0: The impact of socia media on learning in Europe. Seville: Institute for Prospective Technological Studies. Available from http://ftp.jrc.es/EURdoc/JRC56958.pdf

Babbie, E.R. (2010). The practice of social research. Belmont, CA: Wadsworth.

Blunch, N.J. (2008). Introduction to structural equation modelling using SPSS and AMOS. London: SAGE.

Bryman, A. (2006). Paradigm peace and the implications for quality. Internationa Journal of Social Research and Methodology, 9(2), 111-126.

Burrell, G., \& Morgan, G. (1979). Sociological paradigms and organisational analysis. Brookfield, VT: Ashgate.

Cassim, V. (2010). The pedagogical use of ICTs for teaching and learning within Grade eight Mathematics in South African schools. Unpublished master's thesis. NorthWest University, Potchefstroom, South Africa.

Cohen, L., Manion, L., \& Morrison, K. (2011). Research methods in education. (7th edn.). New York, NY: Routledge.

Creswell, J. (2012). Educational research: Planning, conducting, and evaluating quantitative and qualitative research. (4th edn.). Boston, MA: Pearson.

Da Ponte, J.P. (2010). Mathematics teachers' professional development and identity in a distance education setting. In G. Anthony, \& B. Grevholm (Eds.), Teachers of mathematics: Recruitment and retention, professional development and identity (pp. 145-155). Kristiansand, Noruega: SMDF - Svensk Förening för Matematik Didaktisk Forskning.
Da Ponte, J.P., Oliveira, H., \& Varandas, J.M. (2002). Development of pre-service mathematics teachers' professional knowledge and identity in working with information and communication technology. Journal of Mathematics Teacher Education, 5(2), 93-115.

Denzin, N.K., \& Lincoln, Y.S. (Eds.). (1994). Handbook of qualitative research. Thousand Oaks, CA: SAGE Publications.

Department of Basic Education. (2012). Report on the Annual National Assessment of 2011. Pretoria: DBE. Available from http://www.education.gov.za/LinkClick.aspx?f ileticket $=\% 2 \mathrm{~b} 6 \mathrm{~A} 7 \mathrm{GNX} \% 2 \mathrm{fk} 6 \mathrm{o} \% 3 \mathrm{~d}$

Department of Education. (2004). White paper on e-Education: Transforming learning and teaching through information and communication technologies. Pretoria: Department of Education. Available from http://www.education.gov.za/LinkClick. aspx?fileticket= $\% 2$ BfGxKN $\% 2$ FCtg0 $\% 3 \mathrm{D}$

Department of Higher Education and Training. (2012). Green paper for post-school education and training: The doors of learning and culture shall be opened. Available from http://www.saqa.org.za/docs/papers/2012/greenpaper.pdf

Engelström, Y. (2004). New forms of learning in co-configuration work. Journal of Workplace Learning, 16(1/2), 11-21.

Fowler, F.J. (2009). Survey research methods. Los Angeles, CA: SAGE.

Leech, N., \& Onwuegbuzie, A.J. (2007). A typology of mixed methods research design. Springer Science and Business Media, 43, 265-275.

Leendertz, V., Blignaut, A.S., Els, C.J., Nieuwoudt, H.D., \& Ellis, S.M. (2013). Technological pedagogical content knowledge in Grade 8 South African mathematics classrooms: A secondary analysis of SITES 2006 data. Pythagoras, 34(2), Art. \#232, 9 pages. http://dx.doi.org/10.4102/pythagoras.v34i2.232

Mack, L. (2010). The philosophical underpinnings of educational research. Polyglossia, 19, 1-7.

McMillan, J. H., \& Schumacher, S. (2001). Research in education: A conceptual introduction. (5th edn.). New York, NY: Addison Wesley Longman.

Merriam, S. (2009). Qualitative research: A guide to design and implementation. (2nd edn.). San Francisco, CA: Jossey-Bass.

Mertens, D. (2010). Research and evaluation in education and psychology: Intergrating diversity with qualitative, quantitative, and mixed methods. Thousand Oaks, CA: SAGE.

Mishra, P., \& Koehler, M.J. (2006). Technological pedagogical content knowledge: A framework for teacher knowledge. Teacher College Record, 108(6), 1017-1054.

Mueller, R.O. (1996). Basic principles of structural equation modeling: An introduction to LISREL and EQS. Statistics in Medicine, 18(8), 757-758.

Neuman, L.W. (2011). Social research methods: Qualitative and quantitave approaches. (7th edn.). Boston, MA: Pearson.

Patton, M. (2002). Qualitative research and evaluation methods. (3rd edn.). Thousand Oaks, CA: SAGE.

Pelgrum, W.J., \& Law, N. (2008). Introduction to SITES 2006. In N. Law, W.J. Pelgrum, \& T. Plomp (Eds.), Pedagogy and ICT use in schools around the world: Findings from the IEA SITES 2006 study (Vol. 23, pp. 2-12). Hong Kong: CERC.

Sechrest, L., \& Sidana, S. (1995). Quantitative and qualitative methods: Is there an alternative? Evaluation and Program Planning, 18, 77-87.

Strydom, H. (2005). Ethical aspects of research in the social sciences and human service professions. In A.S de Vos, H. Strydom, C.B. Fouche, \& C S.L. Delport (Eds.) Research at grass roots: For the social sciences and human service professions (3rd edn., pp. 56-70). Pretoria: Van Schaik Publishers.

Swan, K., Holmes, A., Vargas, J., Jennings, S., Meier, E., \& Rubenfield, L. (2002) Situated professional development and technology integration: The CATIE Mentoring Program Journal of Technology and Teacher Education, 10(2) 169-190. Available from http://www.rcet.org/research/publications/ situatedpd2.pdf

Western Cape Education Department. (2011). Khanya: Summary of the project Available from http://www.khanya.co.za/projectinfo/?catid=32

Western Cape Education Department. (2013). A brief introduction to the educational districts. Available from http://wced.pgwc.gov.za/branchIDC/ Districts/Districts.htm 